\title{
悪性䋐毛上皮腫の歯肉転移の1例
}

\author{
森 昌彦* ・天野祐史 ${ }^{* *} \cdot$ 坂本幹彦**・木村二郎**
}

\section{A cace of metastatic choriocarcinoma of the gingiva}

\author{
Masahiko Mori - Yuji Amano - Mikihiko Sakamoto - Jiro Kimura
}

\section{緒}

\section{言}

悪性腫瘍の口腔内軽移は従来しばしば報告されている. 主なものを列挙すると Clausen, Poulsen (1964)4) は 1884 から 1961 年での文献的考察で 92 例を報告し Custigliano, Rominger (1954) ${ }^{2)}$ は 1902 から 1953 年 までの計 179 例をまとめており，これはClausen, Poulsen, の報告と同一のものが含まれている. Richard, Cernea, Hennion, Commissionat, Marie (1961) ${ }^{13)}$ は 1892 から 1956 年までのものをまとめ Cash, Royer, Dahlin $(1961)^{1)}$ は 1911 から 1957 年までの 22 例につ いて報告している. 更に近年_Meyer, Shklar ${ }^{8)}$ はTufts 大学を中心とした 12 年間にわたる 29 例の口腔内転移 腫場 25 例を記述し Zegarelli, Tsukada, Pickren, Green. Jr (1973) ${ }^{17)}$ は Rowell Parke 病院における 1955 から 1971 年までの舌転移 12 例を報告している.

これらの報告を通覧すると口腔領域へ転移を示した原 発病巣は乳腺・肺・腎・消化管の悪性腫瘍, メラノーマ, 甲状腺癌などが多く, その他, 前位腺・膀胱・卵巣・子 宮・睪丸・肝蔵・神経・筋の腫瘍が含まれているが䋐毛 性腫湯についてはほとんど述べられていない, 元来, 䋐 毛性腫瘍は日本人を含む東洋人においてその発生率が高 く白人においては比較的まれな疾患であると考えられて いる．著者らの調査した文献において悪性䋐毛上皮腫の 齿肉・口腔への転移症例は 23 例で白人 2 例, マレーシ 了在住の中国人 2 例, 台湾人 1 例, そして日本人 18 例 であった. 1960 年以前の日本における報告は荻野らの 論文に詳細に述べられている。

本症例は脊髄横断症候群を伴った霜肉転移例で, 剖検 により子宮と性器に何ら明らかな腫瘍病巣が認められず

* 岐帛歯科大学口腔外科第一講座（主任：森 昌彥教授）

** 住友病院歯科口腔外科 (主任 : 木村二郎部長)

* The 1st Department of Oral Surgery, Gifu College of Dentistry (Chief: Prof. Masahiko Mori)

** The Department of Dentistry and Oral Surgery, Sumitomo Hospital (Chief: Dr. J. Kimura) 受付 昭和 49 年 8 月 15 日
転移巣の病理学的所見により覀性䋐毛上皮腫と診断され たまれな 1 例である。

症例

女性. 47 才.

主訴

来院時の主訴は次の 4 項目であった（昭和 47 年 9 月 日）

1. 第 1 胸椎以下の脊䯙横断症候群

2. 著明な貧血

3. 歯肉腫瘤の出血

4. 肺腫場の疑い

\section{入院までの経過および現症歴}

患者は昭和 47 年 9 月日頃 1 より何等誘因と思われ るものがなく右前腕背部に疼痛が出現し数日後に両側前 腕尺骨側に痺れ感が加わった. 10 月初旬より上顎前歯部 よりしばしば齿肉出血があり同部に腫瘤があるのに気付 いた．以後来院まで崡肉出血は続いた。この頃より便泌 傾向が強くなり 10 月目腹部に疩れ感が出現した. 10 月】日急に全く歩行不能となり尿失禁も始まった. 10 月—日雨肉出血が極めて著しく止血しない為某市民病 院を受診した.この時約 $1 l$ 程吐血したため $400 \mathrm{ml}$ の 輸血を受け大雨学部口腔外科に転送, 出血部の縫合処 置をらけ止血した. しかし両下肢麻痺が不変のため退院 し10月曰日病院内科を受診した。入院後も著しい 歯肉出血が継続しその処置のため当口腔外科を受診した。

\section{入院時の口腔内および全身所見の概要}

血圧 94/62, 脈拍 120 /分, 眼睑結膜および瓜床は蒼白 であった、只腔内所見は上顎前画部に凝血を伴った母指 頭大の弾力性があり赤味のある軟な腫瘤があった。 211 は欠如しており $1 \mid$ は残根で腫瘤中に埋入していた。畨 肉部の粘膜は一般に発赤し弾性を欠いていた．粘膜出血 などは認められなかった， 口腔清掃状態は良好といえな い. 胸部打聴診・心音異常なく腹部も異常はなかった。 全身のリンパ節腫脹は認められなかった。 赤血球 $182 \times$ $10^{4}$, ヘマトクリット $17 \%$, へモグロビン $5.8 \mathrm{gr} / \mathrm{d} l$, 白 


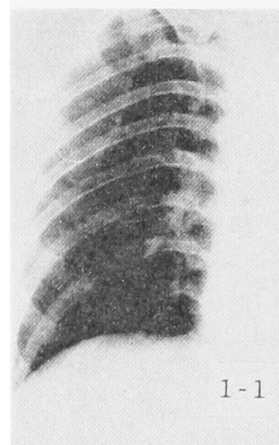

1.1 昭和 47 年 10 月

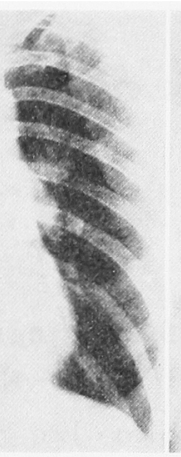

左肺の転移腫的

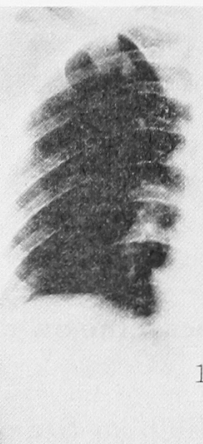

1.2 昭和 47 年 10 月

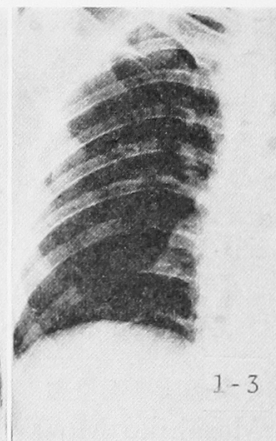

1.3 昭和 47 年 11 月 $\square$

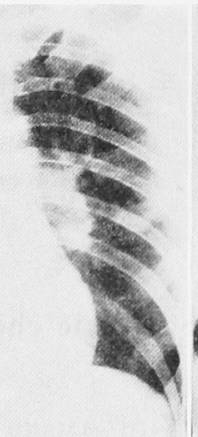

て

写真 1. 肺転移腫演巣の経過

血球 $12,300(\mathrm{~N}=85 \cdot \mathrm{L}=13)$, 血小板 $14 \times 10^{5}$, 出血時 間・凝固時間・プロトロンビン值はいずれも正常範围で あった．血清総蛋白量 $4.8 \mathrm{gr} / \mathrm{d} l, A / G 1.2$, 血清反応 C. R. P. $4 \mathrm{~mm}(+)$ R. A. ( - ) A. S. L. O. 12 todd unit （一）でそして䯣渡に㨟いては圧 $80 \sim 0 \mathrm{~mm} \mathrm{H}_{2} \mathrm{O}$, 蛋白 $200 \mathrm{mg} / \mathrm{d} l$, 細胞 $21 / 3(\mathrm{~L}: \mathrm{N}=4: 3)$ であった。また胸 部X線撮影により肺に病巣があり肺癌が疑われた。（写 真 1-1) ミェログラフィーで第 $4 \cdot 5$ 胸椎のところでブ 口，クサインが認められた．脳神経系には異常なく第 1 から第 5 胸椎の触覚・痛覚の低下, 第 6 胸椎以下の触 覚・痛覚の消失および位置覚そして振動觉消失が認めら れた，両下肢は伸長位をとり低張で深部筋反射消失，病 的反射陰性であった，以後死亡までこの等䯑横断症候群 はあまり変化を認めなかった。

\section{入院時より死亡までの経過と処置の概要}

10 月曰日, 受診時入院

10 月曰日，口腔内腫湯の摘出. 止血と病理学的診断 の目的で摘出が行われた.この時点においては原発病巣 が不明で臨床的に肺癌の転移と考光られた。病理診断は 未分化癌であった。

10 月日，産婦人科受診. 性器出血があるため受診 したが特筆すでき所見は認められなかった。

10 月曰日，大量の下血・性器出血. 呼吸困難を訴元 たので輸血を行った．以後輸血は続いた。胸部X線所見 は（写真 1-2）に示した。

11 月回, 夜間咳濑. X 線により横隔膜上昇, 左肺 門ソンパ節肥大が認められた。

11 月曰日，呼吸困難．入院時よりの腰部荽瘡が著明 となり体位变換を行う際急に呼吸困難となりチアノーゼ が出現し，打診により右肺は濁音を示し下肢は著明な浮 腫状態となった。そして胸部X線像で右肺は無気肺の状 態であった（写真 1-3）. しかし吸引と酸素療法により 改善された。
11 月回日，下血をくり返す．意識昏迷.
11 月回, 死亡.

治療は貪血のコントロール, 蓦瘡の予防, 導尿, 感染 予防，血液ガスチェックに主眼を执いて行われた。総輸 術量は $200 \mathrm{cc} ， 30$ 回，計 $6,000 \mathrm{cc}$ に及んだ. 横断症候 群は知覚・痛覚消失部位が少し変動したぐらいであまり 変化はなかった。

\section{剖 検 所 見}

\section{1. 剖検時所見}

転移腫韵は齿肉・肺臟・腎臓・脳仁あり著しい出血を 伴らむのであった．胃腸の消化管内出血がありこれは新 しい塊状であった．頸椎分節から胸椎分節の変性と脱会道 を認めた。大眼動脈の新鮮血栓症および大動脈のアテロ 一ム性動脈硬化症があった．その他両副腎の脂肪变性・ 左線維性胸膜炎・慢性頸管炎が見られた。

\section{2. 組 織 所見}

腫湯が転移した臟器の組織切片を倹討するとその共通 的特徵は出血像であり明らかに悪性䄉毛上皮腫と考克ら れる合胞細胞とラングハンス細胞が認められた。

剖検所見および病理組織学的所見より次のごとく結論 づけるのが妥当と考元られた（写真 $2 \cdot 3 \cdot 4 \cdot 5$ ).

(1) 齒肉転移腫痬の病理組織学的診断一悪性䄉毛上 皮腫. 先に摘出した口腔内腫瘍の組䄉像を再検討すると 明らかにトロホブラストが認められた。

（2）子宮飞おいては子宮内膜がやや充血している以 外飞悪性栈毛上皮腫を疑わせる所見が何ら見出され得な かった、しかし肺・脳・䨓肉などのすべての転䔟巣の病 理学的診断により原発巣不明のまま悪性䋐毛上皮厙と判 定した.

（3）脊髄横断症候群の発現については脊噵には腫瘍 細胞が認められず頸椎・腰椎の一部変性と脱淔以外飞所 見は認められなかったため春噵血管への腫瘍細胞の塞桎 と考えられた。

なお剖倹後，組織像を検討するあたり配偶者と問診の 結果この患者の最初の娃张は 21 才, 最後は 34 才で 3 年前流産の経験があったことが判明した。 


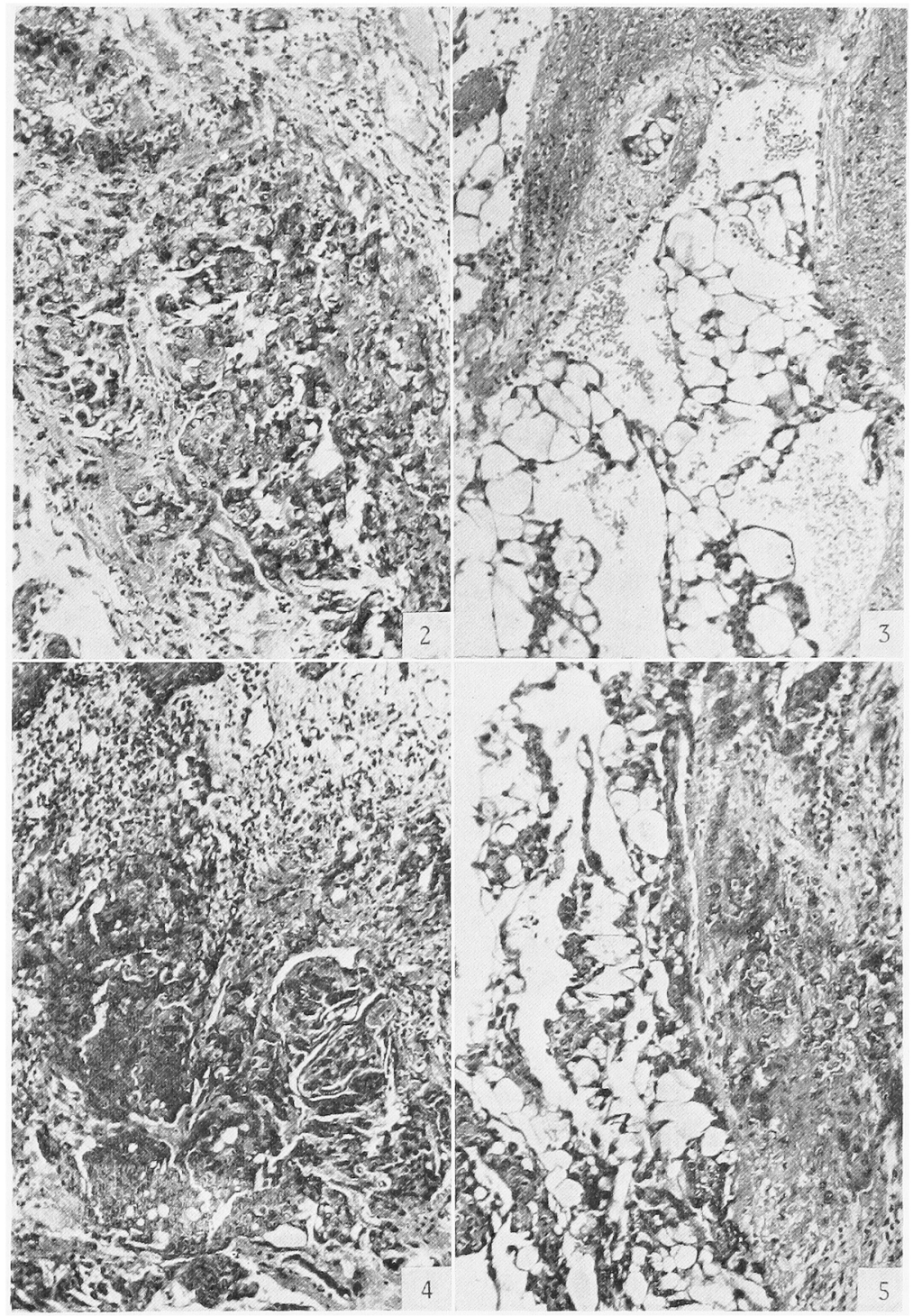

写真 2 5 歯肉火転移した悪性絨毛上皮腫の組織像 $\times 100$

写真 2 Langhans 細胞と合胞細胞 Syncytium cell からなる 腫瘍の部分、円形乃至多角 形の淡く染る原形質で，核 小体の明らかな腫㴦細胞が Langhans 細胞で, 濃染し た原形質で不規則な形の細 胞が合胞細胞である。

写真 3 大きい出血紧と合胞細胞か

考

\section{察}

諸言に述べたごとくロ腔には種々の原発尰瑝の転移が みられ，これらの症例報告はかなりの数にのぼり必ずし
らなる歯肉の転移腫㾴巣。

写真 4 主として合胞細胞と, 少数 の集団をなした Langhans 細胞からなりたつ病巣.

写真 5 合胞細胞の增殖著しく，齿 肉結合織に括いて合胞細胞 と Langhans 細胞の集団が むり,一部の組織は壊死飞 括らいっている。

むまれなるのとはいえない，日本に扎いては䋐毛性腫㯦 の発生は白人より多くまた䋐毛腫瘍の臨休研究も数多く 行われているが，このものの口腔領域の転移例の報告は 少ないようである.著者らの知り得た文献的資料により 
その概要を紹介したい.なお 1935 から 1958 年までの 日本に拈ける 14 例の報告は荻野他（1960）が記載して いるので省略する。

症例 1. (Catania 1953) ${ }^{3)}$ 白人. 21 才. 主訴, 右下 唇の麻痺で歯科受診 (1949. 8. 11). 1945 年下颚部に打 撲をうける. $\overline{432}$ は雪髄死，X線により $\overline{54}$ 附近に根 尖病巣があった．臨床診断，外傷による $\overline{432}$ の茵髄死 と根尖病巣. 全麻で $\overline{432} \mid$ の抜歯を行ら. $\overline{43}$ 小抜崡直 後拍動性出血があり中等度の動脈性出血と思われた。出 血多量のためシ 輸血の結果血圧 106/85 に回復した。抜歯 11 日目に再 び大量出血があり胸部 X線撮影の結果肺に円形病巣を認 め結核の疑いがあった. 1949.9. 四出血のため昏睡に陥 る. 再入院時血圧 $75 / 55$, 脈 $120 \mathrm{~min}$, 胸部X線により 右肺に円形の，そして肺門部に小さい病巣があり腫瘍の 承いがもたれた。問診により 1947.5. 妊娠・搔爬をらけ 1949.】子宮ポリープ除去をらけた．1949.9. 頃から乳 房その他に妊娠の症候が出現し産科医より検査をうけ る.この材料の病理学的診断はブドウ状奇胎であった.

1949. 9. 転医し悪性䋐毛上皮腫の肺転移と診断され た. 子宮全摘, 両側卵巣摘除手術をらけた。胸部X線所 見において肺の転移巣はまずまず桩大していた。 1949. 9.21. 死亡. 死後肺の Punch biopsyにより多数のラン グハンス細胞と合胞細胞を認めた，摘出子宮には悪性䋐 毛上皮腫を認めず子宮腺組織は分泌期で裂胞状を示しり ソパ球の浸潤があった。卵巣の黄体には黄体腔を認めな い. 病理診断, 子宮内膜の decidual reaction, cystic degeneration. 卵巣は multiple corpora lutea.

症例 $2\left(\right.$ Pittsburgh 1957) ${ }^{5)}$ 白人. 21 才. 主訴, 不正出出血・頭痛・複視を訴え

病院を訴れた（1956.2】． 来院 9 週間前に正常出産, その後中等度の出血があり腹痛はない、入院, Pentothal 麻酔で子宮掻爬をらけその結果 retained decidua and chronic endometritis と䛦断された. その直後より 下顎左側前雪部に暗赤色の腫癌が出来て血管腫の様相を 示していた．頭痛・複視は続いて訴えていた，両側の血 管像影と pneumoencephalog ramにより病巣は左側にあ り左側頭室は圧偏されていた，開頭手術の結果大きい硬 膜下血腫と頭蓋内圧の高進を認め脳腫瘍は否定された。

当時より口腔腫瘤から出血があり大きくなり唇舌側にわ たるよらになったので局麻で骨膜下より摘出した（1.7 $\times 1.6 \times 0.8 \mathrm{~cm})$. 歯肉病巣の病理学的所見により悪性䋐 毛上皮腫と䛦断された。その後口腔・直腸からの出血の ため輸血を行ったが血圧 60/30 でショック状態となる. 胸部X線において両肺に多数の転移紧を認めた。㐪肉腫 瘍摘除後 10 日でふたたび再発をみ，大きくなり尰瘍の 增大により咬合不能となった。腫瑒はなお増大を続け表 面は壞死状となった，その間著しい消化管出血と疼痛を 伴う腹部の腫瘤も扗大した。ついに腔転移腫瑄を摘出
したが 2 時間後急に症状悪化し死亡した。剖検の結果 肺・胸膜・肝・脾・腎・脳に転移を認めた。

症例 3 (他 2 名, 東京 1960) ${ }^{11)}$. 51 才. 主訴, $\overline{16}$ 部歯肉の腫脹ならびに出血. 1956.12. 悪性䋐毛上皮 腫のため子宮卵巣摘出. 1959.2. 尿妊娠反応陽性, 化学 療法実施. 8. 四胸部 X線により肺における腫瘍転移を 疑った.9.】試験開胸の結果肺全体に小指頭大の転移 巣を認め病理学的に確認された. 10. 突如口腔出血.

10. 回局所麻酔で転移腫瘍の摘除を行った。な扣 10 . より $200 \mathrm{R}$ のX線治療を計 4 回（10.】 まで）行った. 10.】より Carcinophilin 療法を行ったが 11. 回死亡. 剖検により両肺・心襄前頭葉に転移が認められた.

症例 4 台中, 1961) ${ }^{14)}$. 台湾人. 46 才. 主 訴, 76 抜崡後の大量出血之新生物. 正常妊娠 4 回, 最 終分婏 38 才. 4 年前に胞状奇胎の手術をらけた. 2 年 前に悪性䋐毛上皮腫により子宮全摘, Nitromin, 放射線 療法により治癒・ 1 力月前に $\overline{76} \mid$ の煩側に隆起あり, 時に出血するので 76 を抜去した．来院時 76 の抜歯 窩にくるみ大 $(2.5 \times 2.0 \mathrm{~cm})$, 円形，灰白色の一部出血 斑のある腫瘍あり．発育は速で悪臭があった．放射線療 法 2 回実施した. そしてその後死亡した. 最終診断は歯 肉腫瘍より悪性䄉毛上皮腫とされた。剖検により肺・脳 に転移を認めた。

症例 5 (他 2 名, 行古屋, 1962) ${ }^{12}$. 29 才, 主訴, 歯肉の出血性腫瘤と貧血. 隀㰾は有茎性であり Epulis の臨床診断のもとに試験切除を行ったが原発部 位を確認出来ず，更に全摘により悪性䋐毛上皮腫と診断， 肺の病楽もこの転移と考えられた。輸血, Tespa療法を 行ったが死亡した. 新検は行はれず詳細不明.

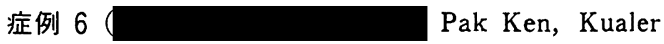
Lumpur, 1968) ${ }^{12}$. マレーシア在住の中国人.22才. 主 訴, 疼痛を伴う上顎腫瘍の出血（1967.4.】吕 Lumpur 総合病院へ来院した，上顎前歯を被う大きな腫 瘍があった。この患者は 1963.12. 回性器出血で婦人科 入院. 子宮は妊娠 10 週の大きさで Douglas 腔にオレン ジ大の腫瘤があり同月曰日择爬の結果病理所見は血餅と chorionic villis および trophoblastic tissue であった. 1964.1. 性器出血のため再入院. 病理診断は actively proliforating trophoblastic tissue で Prepuerin Test 陽性，胸部X線所見陰性で methotrexate 療法を行った。 1965. 3. 四性器出血, 子宮は妊娠 10 週の大きさで 2 回目 の methotrexate 療法を実施した５.】2 日にわたる 出血のため再入院. 6. 田宮全摘をらけ病理学的に悪 性絾毛上皮腫の診断がなされた. 1966.11. 目前歯部の疼 痛と腫張のため抜歯をらけ同時に biopsyをとる。病理 診断は high anaplastic, quite undifferentiated tumor であった１967.5. 四発した上顎前齿部腫瘍の病理診 断の結果転移性悪性絨毛上皮腫と决定した. 10 月 toad test $1: 1.280$ で陽性. 胸部X線所見で 2 つ転移病宩 
表 1

\begin{tabular}{|c|c|c|c|c|c|c|c|}
\hline \pm & 年・国籍 & 訴 & 臨㦿診断 & 婦人科的診断及び徵候 & $\begin{array}{l}\text { 肺転移 } \\
(\mathrm{X} \text { 線) }\end{array}$ & \begin{tabular}{|l|} 
死亡時の \\
転移巣 \\
\end{tabular} & $\begin{array}{l}\text { 確定病 } \\
\text { 理的䧐断 }\end{array}$ \\
\hline $\begin{array}{c}\text { Case } 1 . \\
\text { (1953) }\end{array}$ & 21 . 白人 & 43 部の腫脹 & $\begin{array}{l}\overline{432} \mid \text { 部の外偪 } \\
\text { 性罴胞 }\end{array}$ & $\begin{array}{l}\text { 妊娠揸爬・ 子宮 polyp 妊娠症候・ } \\
\text { 胞状奇胎 }\end{array}$ & $\begin{array}{l}\text { 右肺大円 } \\
\text { 形莪左肺 } \\
\text { 小円形策 }\end{array}$ & 不明 & $\begin{array}{l}\text { 死亡後の } \\
\text { 肺転移夈 } \\
\text { punch } \\
\text { biopsy }\end{array}$ \\
\hline $\begin{array}{c}\text { Case 2. } \\
\text { (1957) }\end{array}$ & 21. 白人 & $\begin{array}{l}\text { 䛎出血頭・痛 } \\
\text { 複・視下顎前 } \\
\text { 歯部の腫脹・ } \\
\text { 出血 }\end{array}$ & 血管腫？ & 出産後の出血・左腰痛 & $\begin{array}{l}\text { 両肺多数 } \\
\text { の転移紧 }\end{array}$ & $\begin{array}{l}\text { 肺・胸膜・ } \\
\text { 肝脾・・腎・ } \\
\text { 腷 }\end{array}$ & $\begin{array}{l}\text { 崡肉転移 } \\
\text { の摘出物 }\end{array}$ \\
\hline $\begin{array}{l}\text { Case } 3 . \\
(1959)\end{array}$ & $\begin{array}{l}51 . \\
\text { 日 } \text { 本 人 }\end{array}$ & $\mid$\begin{tabular}{|c|}
$\overline{6}$ 部櫣肉 \\
腫脹・出血
\end{tabular} & $\begin{array}{l}\text { 悪性䋐毛上皮 } \\
\text { 腫の口腔転移 }\end{array}$ & $\begin{array}{l}\text { 胞状奇胎手術, 悪性䋐毛上皮腫の診 } \\
\text { 断で子宮卵宩の全剔出 }\end{array}$ & $\begin{array}{l}\text { 転右肺下 } \\
\text { 葉部の移 } \\
\text { 单 }\end{array}$ & $\begin{array}{l}\text { 両肺・心 } \\
\text { 覆・左前 } \\
\text { 頭葉 }\end{array}$ & $\begin{array}{l}\text { 試験的開 } \\
\text { 胸術 }\end{array}$ \\
\hline $\begin{array}{c}\text { Case } 4 . \\
(1961)\end{array}$ & 台 ${ }^{46 .}$ 湾 人 & 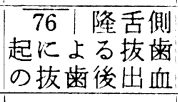 & ? & $\begin{array}{l}\text { 胞状奇胎手術 }(4 \text { 年前) - 悪性䋐毛 } \\
\text { 上皮腫 }(2 \text { 年前 }) \text { - Nitromin 療法 }\end{array}$ & 肺転移 & 肺 · 脳 & $\begin{array}{l}\text { 歯肉転移 } \\
\text { 桠 }\end{array}$ \\
\hline $\begin{array}{l}\text { Case } 5 . \\
(1962)\end{array}$ & $\begin{array}{l}22 . \\
\text { 日 本人 }\end{array}$ & \begin{tabular}{|l} 
歯肉の出血性 \\
腫瘤
\end{tabular} & $\begin{array}{l}\text { エプーリス, } \\
\text { 肺腫㾴の歯肉 } \\
\text { 転移 }\end{array}$ & $\begin{array}{l}\text { 妊娠症候, 胞状奇胎, Friedmann } \\
\text { 反応強陽性 }\end{array}$ & $\begin{array}{l}\text { 右肺 } 4 \times \\
4.5 \mathrm{~cm} \text { の } \\
\text { 陵影 }\end{array}$ & 不明 & $\begin{array}{l}\text { 歯肉転移 } \\
\text { 采 }\end{array}$ \\
\hline $\begin{array}{l}\text { Case } 6 . \\
(1968)\end{array}$ & $\left.\mid \begin{array}{ll}22 . & \text { 中国人 } \\
\text { マ } & \text { レーシ } \\
\text { ア在住 }\end{array}\right)$ & $\begin{array}{l}\text { 上顎前歯部腫 } \\
\text { 瘤の出血 }\end{array}$ & ? & $\begin{array}{l}\text { 胵出血，妊娠反応丹，覀性䋐毛上皮 } \\
\text { 腫の疑い, methotrexate 療法 }\end{array}$ & \begin{tabular}{|l|} 
左肺直径 \\
$1 \mathrm{~cm}$ 病 \\
果
\end{tabular} & 不明 & $\begin{array}{l}\text { 歯肉転移 } \\
\text { の摘出物 }\end{array}$ \\
\hline $\begin{array}{l}\text { Case } 7 . \\
(1971)\end{array}$ & 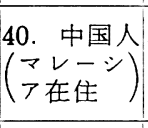 & 與咽腔癌の寲 & 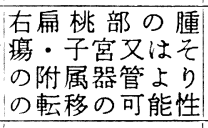 & 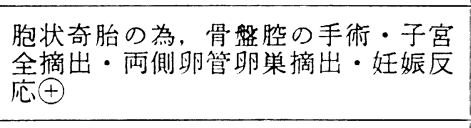 & $\begin{array}{l}\text { 肺転移栄 } \\
\text { (死亡 } 2 \\
\text { 日前) }\end{array}$ & 不明 & $\begin{array}{l}\text { (臨床病 } \\
\text { 理的総合 } \\
\text { 診断) ? }\end{array}$ \\
\hline $\begin{array}{l}\text { Case } 8 . \\
\text { (1973) }\end{array}$ & $\begin{array}{l}32 . \\
\text { 日 } \text { 本 人 }\end{array}$ & $\begin{array}{l}\overline{1 / 12} \text { 歯肉の } \\
\text { 腫瘤・出血 }\end{array}$ & & 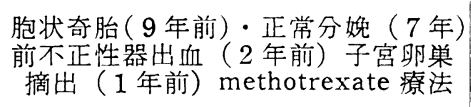 & 肺転移 & $\mid \begin{array}{l}\text { 肺・肝・ } \\
\text { 腎・脳 }\end{array}$ & $\begin{array}{l}\text { 歯肉転移 } \\
\text { 皇 }\end{array}$ \\
\hline
\end{tabular}

を発見した５.】より methotrexate 療法を行い上顎 腫瘍の大きさは半分になったが 7.ロ 死亡した。

症例 7 ( Kualer Lumpur 1971) ${ }^{7}$. マレーシア在住の中国人. 40 才。主訴，鼻咽腔癌の疑 いで市民病院に来院(1969.8.回)，右扁桃腺に腫瘍があ り同側頸部リンパ節腫脹をきたしていた，既往歷と肉眼 所見より子宮からの転移の可能性があった．1965. 回胞 状奇胎のため出血. 9 月子宮全摘と両側卵管卵单摘出術 をらけた，子宮内容は血液で充満し病理学的に筋層に至 る trophobastic tissue の浸潤があり出血と壊死を伴っ ていた．胸部X線は陰性. 1965.8.1. 婦人科的所見を何 等認めないが P-test $(1: 200)$ で陽性, 胸部X線により 肺に典型的の転移巣を認めた（死亡 2 日前).

症例 8 (他 6 名. 大阪. 1973) ${ }^{10)} 32$ 才. 主訴, $\overline{1 \mid 12}$ の歯肉腫瘍と出血のため台腔外科を訪れた （1972.2. . 1963.6. 胞状奇胎で子宮搔爬. 1965. 分 娩. 1970.2. 加ら不正出血. 1971.4. 子宮・卵巣摘出術 をうけたが Friedmann 反応陽性. 胸部X線により左肺 に転移巣あり，methotrexate 療法を行う。来院時の歯 肉腫瘍の病理学的診断により覀性䋐毛上皮腫と決定した。 肺よりの出血, 強度の悪心・嘔吐により 1973.1. 死 亡. 剖検により歯肉の他, 脳・肺・服・腎に転移栄を認 めた。

このように本症例を含めて報告された粷肉・口腔の転
移症例については共通の所見が見られる。すなわち，歯 肉などに転移した悪性䋐毛上皮腫は出血の傾向が著しく 症例においては血管腫様を示し，また症例 1 においては 抜萊により大出血を示しており，この臨床所見は通常， 異常性器出血その他消化管出血においても著しいまた 多くの症例においては既往歴において分婏, 胞状奇胎お よび悪性䋐毛上皮腫があるのを原則としている6 ${ }^{6}$. しか し，ここで問題となるのは本症例および症例 $1 \cdot 2$ にお いて婦人科的に細胞診または子宮内容物の病理学的診査 において明確に悪性䄉毛上皮腫と診断されず雪肉・肺・ その他の転移病巣の検査により本症が診断されたことで ある. 更に注意すべきことは今までに報告されたすべて の症例に打いて生前肺転移を認めている.この場合, 肺 のX線所見においてその病巣が必ずしも肺への転移腫瘍 とは判定されず肺の原発病巣を疑らこともしばしばあり 疾病の診断に䛊謬と遅延を来していることが多い，悪性 䋐毛上皮腫はしばしば血行的に肺へ転移することが知ら れているが6)，この場合原発笨が明らかである場合には 臨㦿上問題は少ない。しかし本症例やすでに報告された 数少ない症例において原発病巣の診断が不明または未定 のまま肺の腫痬所見を示すので，この肺病巣が転移性か または原発性かが諭議の的となるわけである、肺に転移

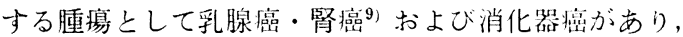
これらの悪性腫瘍が原発病巣不明のまま肺に転移を示し 
た場合に，悪性䋐毛上皮腫の転移と鑑別することが重要 である，また，悪性䋐毛上皮腫は男女をとはず異所性に 発生することがあり口腔の異所性䋐毛上皮腫の報告があ る(新藤 1935). 更に本腫瘍は子宮の原発病巣の蛊爬ま たは除去により遠隔転移病栄の自然治癒がみられたとい ら報告もある. しかし本症例は性器その附属器において 明らかに悪性䄉毛上皮腫といら組織学的所見が得られな かったが，まれな原発病巣の治癒例とは考えていない. 一応原発病巣不明のまま悪性䋐毛上皮腫の全身広汎転移 の現象としてロ腔転移が出現したものと考えられる.そ してこの口腔転移はすでに発表された論文に述べられて いるごとく, 一次転移臓器である肺からの二次転移の末 期症状と考えられる.

\section{結}

\section{論}

47 才女性, 第 1 胸椎以下の著明な貧血を伴う脊髄横断 症候群, 肺腫瘍と口腔内転移性腫瘍からの出血の主訴で 来院, 入院. 死亡後剖検により悪性䄉毛皮腫の転移と判 明したまれた症例を報告した。本症例は入院時肺腫瘍の 口腔転移の疑いがあり，婦人科的特徵を示さず剖検によ り原発不明のまま悪性䋐毛上皮腫の遠隔転移と診断され たもので, 脊䯣横断症候群は脊髄動脈の腫瘍細胞の栓塞 によるものと考えられた. 入院より死亡までの臨床所見， 肺のX線所見, および病理組織学的所見の詳細を述べ, すでに報告された悪性䄉毛上皮腫の口腔転移症例につい て考察を加えた。

稿を終えるにのぞみ臨床病理学的所見および剖検につ き種々御教示頂いた。住友病院臨床検査病理部長, 井 洋平先生に感謝の意を表します。

\section{文 献}

1) Cash, C. D., Royer, R. Q. Dahline. D. C. : Metastatic tumors of the jaws. Oral Surg 14: $897 \sim 9051965$.

2) Castigliano, S. G., Rominger, C. J. : Metastatic malignancy of the jaws. Am J Surg $87: 496 \sim 5071954$.

3) Catania, A.P. :Three nonvital teeth associated with chorioepithelioma. report of case. J. Oral
Surg $11: 324 \sim 3301953$.

4) Clausen, F., Poulsen, H. : Metastatic carcinoma to the jaw. Acta path microbiol Scand $57: 361 \sim 3741963$.

5) Englert, R. J., Pasqual, H. N. : Metastatic chorionepithelioma of the gingival tissue. Oral Surg $10: 931 \sim 8181957$.

6) 長谷川敏雄 : 䋐毛性腫疾. 医学書院 1967, 東京, $229 \sim 232$ 頁

7) Kutty, M. K. , Shenoy, A. V. : Metastatic choriocarcinoma of the tonsil following hysterectomy for an invasive mole. and a period of "inactivity" of trophoblastic tissue. Oral Surg $10: 813 \sim 8181957$.

8) Meyer, I., Shklar, G. : Malignant tumors metastatic to mouth and jaws. Oral Surg 20: 350 362 1965.

9）森昌彦, 他：歯肉に転移した叟癌の 1 例. 一原 発腎腫癔の口腔への転移に関する文献的考察一日 口外誌, $20: 6141974$.

10）西尾順太郎，他：歯肉に転移を来たした悪性䋐毛 上皮腫の 1 症例(会). 口科誌 $22: 2131973$.

11）荻野益男, 他：口腔内転移を示した悪性䋐毛上皮 腫の 1 例について. 口外誌 6:515 520 1960 .

12) Ramanathan, K., Eravelly, J., Pak Ken, T.: Metastatic choriocarcinoma involving the maxilla. Oral Surg $26: 688 \sim 6931968$.

13) Richard, A., Cernea, P., Hennion, P., Commissionat, Y., Marie, M. P.: Les epitheliomas metastitiques de la mandible. Rev Stomatol. $57: 652 \sim 6731956$.

14）石 泰三: 悪性絨毛上皮腫が歯艱に転移した 1 例 (会). 口外誌 $7: 197 \sim 1981960$.

15）新藤正雌：11）より引用

16）柘植精一，他：悪性脈絡膜上皮腫の歯肉転移の 1 例. 医療 $19: 196 \sim 1971962$.

17) Zegarelli, D. G., Tsukada, Y., Pickren, J. W., Green Jr. G. W. : Metastatic tumor to the tongue. Report of twelve cases. Oral Sung $35: 202 \sim 2111973$. 